\title{
How Central Water Management Impacts Local Livelihoods: An Ethnographic Case Study of Mining Water Extraction in Tarapacá, Chile
}

\author{
Sascha M. Cornejo P. ${ }^{1,2, *(D)}$ and Jörg Niewöhner ${ }^{1,2, *}$ \\ 1 IRI THESys, Humboldt-Universität zu Berlin, 10117 Berlin, Germany \\ 2 Institute of European Ethnology, Humboldt-Universität zu Berlin, 10117 Berlin, Germany \\ * Correspondence: scornejopuschner@gmail.com (S.M.C.P.); joerg.niewoehner@hu-berlin.de (J.N.)
}

check for updates

Citation: Cornejo P., S.M.;

Niewöhner, J. How Central Water Management Impacts Local Livelihoods: An Ethnographic Case Study of Mining Water Extraction in Tarapacá, Chile. Water 2021, 13, 3542. https://doi.org/10.3390/w13243542

Academic Editor: Carmen Teodosiu

Received: 15 October 2021

Accepted: 7 December 2021

Published: 10 December 2021

Publisher's Note: MDPI stays neutral with regard to jurisdictional claims in published maps and institutional affiliations.

Copyright: (c) 2021 by the authors. Licensee MDPI, Basel, Switzerland. This article is an open access article distributed under the terms and conditions of the Creative Commons Attribution (CC BY) license (https:// creativecommons.org/licenses/by/ $4.0 /)$.

\begin{abstract}
Chile's neoliberal central water management gives shape to a series of conflicts arising from diverse understandings and ways of life linked to water. This article addresses the question of who is responsible for the ecological costs regarding water use of mining activity in the north of Chile. From the perspective of hydro-social territories, we analyze how the local population in Tarapacá is acting on unequal footing regarding environmental information and knowledge. Local and practical experiences are devalued against technical and scientific modeling, supported by legal and political definitions of "the environment" and "water". Focusing on diverse local narratives, we show how the local population feels threatened by the environmental impacts of mining activity but struggles to find legitimate ways of articulating those anxieties to gain a sense of agency. We conclude that the local ecological consequences of extractivism in this region can only be understood in the context of the wider legal and economic framework regulating the appropriation of water as a resource and that long-term efforts in more participatory sociohydrological modeling might help to broaden the knowledge base for contested decision-making.
\end{abstract}

Keywords: environmental conflicts; local knowledge; hydro-social territories; neoliberalism; hydrological modeling; Chilean water code; Atacama Desert

\section{Introduction}

Water is a central issue in the current debate about Chile's new political constitution, which carries the promise of reconfiguring the relationship between nature, corporations, and civil society as practiced in resource extraction. In the current context of post-social protest of October 2019 and the consequent demands from civil society to transform the highly neoliberal Chilean political constitution, there is an ongoing discussion about the political legacy of the authoritarian impositions of the Pinochet dictatorship. It was under Pinochet's mandate that the regulatory framework regarding nature and resource use was constituted to favor private and transnational companies.

Chile's productive sector is based on the country's production of raw materials. Copper mining accounts for around $10 \%$ of GDP, $50 \%$ of total exports, and $35 \%$ of total public investment in natural resources [1] (p. 23). In 2021 the Chilean Copper commission (COCHILCO) published an estimate of expected investment in Chile in the period of 2021 to 2030. The projection showed a total of 51 mining initiatives planned in the country, for an amount of USD 68,925 millon. $27.8 \%$ invested by the state-owned company CODELCO and $72.2 \%$ by private mining companies, the latter concentrated in copper mining, which accounts for $78.4 \%$ of the total amount of investment [2]. Mining activities put a lot of pressure on the environment and often lead to environmental conflicts with high associated costs. As a study published by the Chilean government shows, despite investment showing an upward trend, around 46 investment projects worth USD 57.87 million were halted in 2016 due of different environmental conflicts [1] (p. 26). Today, then, the question of 
whether and how mining royalties should lead to fair payments to the regions impacted by mining is currently being discussed widely.

In this context, the discussion about the social, political, and ecological consequences of water supply and distribution is in full swing. For some experts and NGOs, the reform of the key piece of this regulatory framework, the Chilean Water Code, is seen as an urgent project to guarantee the protection of the human right to water for the Chilean people [3-6]. In this paper, we support this call for reform and argue for a more responsible form of regulation by demonstrating how the current regulatory framework with its neoliberal history cannot account for different forms of knowledge and livelihoods as they relate to water in multiple ways.

For more than a century, political discourses have linked resource extraction to longdesired development in Chile [7-12]. At the end of the 19th Century, mining was already present in the north of the country and in the Andean area in general. After the Pacific war between Peru, Bolivia, and Chile, Peruvian and Bolivian territories were annexed by Chile and exploited for their mineral wealth $[13,14]$. At the beginning of the 20th century, the Chilean state promoted nationalist policies that still remain in people's memories today. This process of a so-called "Chilenization" sought to install Chilean nationalism in the Peruvian, Bolivian, and Indigenous populations through the implementation of schools and compulsory military service [15]. Salpeter exploitation was one of the most prosperous activities, which helped to shape the imaginary of a Chilean "North" defined by mining [16]. Today, the old Saltpeter towns in Tarapacá act as powerful symbols of a future past; socio-technical imaginaries that once saw the region and with it the whole country strived towards the national goal of modern economic development. Today, it is mainly copper, silver, lithium, zinc, and other mineral and non-mineral resources extracted in these territories. However, the contradictions and interconnections within and between these imaginaries as well as the treatment of nature solely as a resource have been widely discussed in research on Latin American extractivism, post-colonial theory, and political ecology [10,17-27].

Environmental conflicts are inherent to resource extraction. In the case of mining, conflicts are often exacerbated by the significant water demands associated with it [4,28-34]. Moreover, water is a fundamental resource for mining [35] (p. 7) [36,37]. In Chile, the water used is predominantly groundwater and the right to extract it is granted by the state authorities. However, considering a growing water shortage produced by climate change and a current mega-drought, the Chilean mining industry projects an increasing use of salt water through desalination [36].

Water is a highly relational phenomenon that shows a complex story in which institutional arrangements enter, are handled, and impact on specific local contexts confronting in various ways ideas and narratives of locally concerned communities [38,39]. Therefore, we will use the theoretical framework of hydrosocial territories [40] to address these tensions and contradictions, highlighting the differences in perceptions and practices between local communities, state institutions, mining companies, and local authorities in their attempts to enact the territory they consider legitimate and plausible. We focus primarily on the local assemblages of practices and legal mechanisms that shape the agency of human and non-human actors alike. Yet we analyze hydrosocial territories within the broader historical context of Chile's neoliberal legislation-imposed without any consent from civil society-to not only question the particular consequences of legal and juridical definitions, but also the onto-epistemic tensions underlying hydrological modeling and socio-political struggles over what counts as legitimate knowledge and subsequently what water can be in the region of Tarapacá and beyond. We pay particular attention to the ways knowledge is constructed, used, and mobilized and the role of hydrological models in this process. To develop this analysis on an empirical basis, we focus on the case of the Pica Oasis. We first outline our conceptual framework based on hydrosocial territories, scientific models, and uncertainty. We then set out the current system of water rights in Chile before analyzing 
our case study of Pica with a particular focus on contestations of water stress through claims to alternative hydrosocial territories.

\section{Atacama Desert under the Scope of Hydrologic Modeling and as Hydrosocial Territory}

Our conceptual framework centers around the notion of hydrosocial territories and an understanding of scientific models as political actors. Both approaches complement each other insofar as they attend not only to a territory and its disputes over water resources but allow us to place a particular focus on the role of knowledge and scientific evidence in these disputes.

\subsection{Hydrosocial Territories}

We start from the assumption that any form of management of the hydrological cycle is political in nature and, consequently, open to critique and dispute [41]. We understand water management as a socio-material issue in which hydrology, infrastructure, power relations, political agreements, legislation, and environmental regulations play a decisive role $[32,42]$. This approach highlights the normative character of water resource regulations and how hydrosocial territories can "help advance a better understanding of interrelated local, regional, national and international processes of water governance and the issues of equity and justice in water control." [40] (p. 1). We strive to overcome dualistic understandings of a "natural" world intervened in by "human" political or legal devices and arrangements $[43,44]$. Instead, we focus on the multiple entanglements of material, political, and normative dynamics within a field of tension in which water represents a disputed issue among different social actors. It is not only the idea that water can become different "things" [45], but how these different things are related to the definitions, arrangements, allocation, and distribution of water resources [46]. We emphasize the dynamic character of these relations through which technology, expertise, and social imaginaries meld in networks or confront each other [47].

As a first conceptual approach, Boelens and colleagues define hydrosocial territories as a "contested imaginary and socio-environmental materialization of a spatially bound multi-scalar network in which humans, water flows, ecological relations, hydraulic infrastructure, financial means, legal-administrative arrangements and cultural institutions and practices are interactively defined, aligned and mobilized through epistemological belief systems, political hierarchies and naturalizing discourses." [40] (p. 2). These intersections between water and territories imply multi-scalar and plural understandings of the notion of territories linked to socio-natural imaginations in dispute [48] that "are continuously contested and renegotiated by diverse actors engaged in particular acts of territory making within the same time and space" [49] (p. 152). Following Hommes' idea that territories are not fixed spaces [49] (p. 152), socio-natural elements such as water are dynamically configured by legal means and state agencies [5,42,50-52]. These configurations favor certain actors and stakeholders, positioning them in a field of dispute against other forms of life and living through water and practices based on it [53-55].

Beyond local water practices, then, this specific reading of the hydrosocial territories framework will allows us to focus on the relationships between governmental institutions and the rule of law as a terrain contested by local populations [30]. However, local life experiences often engage critically with techno-scientific knowledge, e.g., hydrologic modeling, highlighting, and criticizing a "common game" between politics, law, economic interests, and knowledge. Conflicts are thus often due to the power asymmetries implicit in legal regulations $[38,56]$.

Different modeling frameworks have acknowledged that such sharp distinctions between local and expert knowledge must be treated with care. Instead, interdisciplinary approaches have been suggested that allow for dialogue between different knowledge systems in diverse fields such as climate change adaptation [57] or water allocation [58]. Various methodologies have been developed that seek to incorporate and encourage the participation of local actors and stakeholders in the shaping of a more "holistic" and 
"democratic" knowledge base in and for modeling [59]. Such participatory modeling has been implemented in a number of cases [57,60-62].

\subsection{Hydrological Modeling as Political Actor}

Scientific models help to make territories legible and resourceful [63]. Yet models are only one way of making territories meaningful to people. Many other, often local practices of meaning-making exist. Oftentimes, state interventions are based only on technical knowledge (techne) and sideline or ignore local knowledges (metis). This discrepancy sets interventions up for missing public acceptance, failure, and injustice. Employing the tensions between different forms of "evidence" building as a heuristic, we oppose here local community experience to scientific models $[64,65]$ as two different epistemic registers. We draw on studies that have challenged the supposed superiority of scientific knowledge over non-scientific understandings [66] and that read the dichotomy between "scientists" and "ignorants" as a response to a "crisis" of legitimacy of science itself [67-70]. Thus, Wynne's seminal work on the relationship between scientific advisors and farmers in the Chernobyl-affected area of the UK shows how distrust can grow between actors if local populations and their knowledge are dismissed as "ignorant" or "backward". Wynne's and Jassanof's work have problematized the difficult relationship between a non-expert public that must submit to decisions based on scientific evidence and are not taken into account in decisions that may affect them. Problems of mutual mistrust, but also growing uncertainty are part of the elements that hinder these relationships [71]. On the other side, the work of Jasanoff builds on the idea of co-production as a form to overcome these contradictions [71]. As she recently pointed out regarding modeling in the time of Anthropocene and climate change: "Experts offer facts, and facts have the capacity to cut through the mist of competing images, replacing interpretive flexibility with discernible causes and reasons. ( ... ) Inevitably, therefore, science and technology influence the dynamics of power." [72] (p. 11). Hence, Jasanoff points to the close entanglements between science, capital, markets, and law. Particularly "in-the-way-of-development-countries", where extractive projects such as mining have high symbolic and financial value [73], it is no longer conceivable that models simply reflect scientific objectivity and are thus understood as neutral representations. Instead, models become instruments to make visible and legible natural resources in particular ways [63] and thus also instruments to fuel particular imaginaries, legitimate extractive interventions, and ultimately shape promises of modern development and associated understandings of nature as a resource only. Scientific models, understood in this sense, become political actors or "actants" [74] that can and need to be held accountable, not only against inner-scientific criteria of knowledge production but also against wider political and ethical concerns about "more-than-human livability" [75] in the hydrosocial territories which the models help to shape. How does modeling help to make hydrosocial territories and make those territories legible [63]? Different forms of uncertainty are crucial in this context as they point to the limits of predictability and their consequences (e.g., risk analysis): "Uncertainty is not the opposite of knowledge but a constitutive relationship that acknowledges the role and value of knowledge to projects of living. It operates affectively as an open deeply felt apprehension, in which people know enough to imagine the different ways dangerous situation may turn out." [76] (p. 6). Models thus become devices that implement bridges between anthropogenic projection and action, between environment and infrastructure [76,77]; a projection that leaves behind the incommensurable, that which does not enter and fit into the calculation, that which does not enter as "data". Thus, the space of uncertainty, although an important aspect of scientific work [78-81], extends beyond expert knowledge. It is experienced and evidenced in the multiple ways of understanding the environment which are not subjected to scientific scrutiny $[60,82]$. With this pragmatic effect, models severely impact the ecosystems and territories they characterize or define, but also local expectations on how things need to be done. Uncertainty is lived and experienced and stands for the unforeseeable. It 
is experienced by local people in other live projects, which do not resonate with high modernism, and it is linked to intense feelings of distrust, anguish, or even fear.

\section{Methodological Approach}

Pursuing a multi-sited ethnographic approach of "following the conflict" [83] that allows us to chart and understand the competing positions, practices, and reasonings within hydrosocial territories, the following case study analysis is based on five months of ethnographic fieldwork conducted in the region of Tarapacá, Chile, and 50 semi-structured narrative and problem-centered interviews conducted from March 2018 to March 2021 in Spanish without translation. Key interviews were held with Indigenous leaders in the region (18), with assessors of the Indigenous communities helping them to defend their interests against mining expansion through contesting environmental impact assessments (6), farmers and community spokespersons at Pica Oasis (4), representatives from mining companies in charge of "community relations" (2) and state officials (4) from the responsible environmental agency (Environmental Assessment Service, SEA) and the General Water Directorate (DGA). It is worth mentioning the role of assessors as some of them have had the experience of working for "both sides", for the companies and for the communities. The advisors are those who provide the technical arguments to construct and defend or to criticize the environmental impact studies within which the hydrogeological models constitute the scientific proof and evidence to support the realization of a given project.

Fieldwork in the region mainly focused on participant observation during and around public presentations of new mining projects, a common practice within the current Chilean environmental regulation system. Limited participant observation was complemented by extended informal and semi-formal conversations through social media. Due to the restrictions imposed by the government to control the pandemic, the second phase of fieldwork between December and March (2020-2021) could not be carried out "in situ" in Tarapacá. Nevertheless, several interviews and more informal conversations were conducted via telephone, whatsapp and Zoom. This approach made it possible to sustain conversations with several local leaders over time and thus enabled us to follow the unfolding of a conflict within the territory over two years.

Sascha Cornejo P. conducted all interviews and conversations as part of his $\mathrm{PhD}$ research on mining conflicts in the Tarapacá region, Chile. All empirical work was conducted following the guidelines of the American Anthropological Association for fieldwork. We obtained prior informed consent from participants on the context and use of the data. In order to protect the identity of participants, interviewees have been anonymized. In his fieldwork, Cornejo implemented participatory methodologies that conform to the criteria of reciprocity, values widely spread in the Andean area. To this end, he has shared part of the written documents developed in the research context (2018-2021) and implemented workshops in order to share research findings with the study participants (2020). The interviews were conducted following a guide with open questions which touched upon the key topics of water stress, cultural change, negotiations between Indigenous communities and mining companies, resistance processes, environmental impacts, environmental consciousness, and knowledge construction in response to environmental impact assessments. Whenever possible, interviews were audio recorded and transcribed verbatim. The entire empirical material was coded in a qualitative analysis following an iterative inductive and deductive coding process [84] supported by the software Atlas.ti.

\section{Regulatory Framework for Water Use in Chile}

In Chile, agriculture and mining are the production sectors which consume the most water, altogether about $85 \%$ of the total water consumption nationwide [85]. Agriculture consumes about $82 \%$, mining $3 \%$, industry $7 \%$, and water user services about $8 \%$ according to the Chilean Water Atlas [85,86]. Consequently, the need for water is a real challenge for long-term development and it is considered an important strategic resource with demand expected to grow [87] (p. 6) [35,88]. The Chilean legal system separates water from land, 
turning water into an asset that can be used independently of land ownership. The Chilean state is the owner of water as established in the Water Code of 1981. Water is defined as a "public good" (Art. 5), but its "use" is granted through a so-called "right to use" (in Spanish: "Derecho de Aprovechamiento"), enforced and granted by state authorities. According to a guide for the application for the use of groundwater (which is the one we are interested in here), the application must present several points: 1 . The applicant's information. 2 . The nature of the water (groundwater), the commune, and province in which the catchment is located. 3. The maximum flow that needs to be extracted at a given time, expressed in metric and time measurements $(\mathrm{L} / \mathrm{s})$, and the total annual volume to be extracted from the aquifer, expressed in cubic meters. 4 . The use to be made of the requested water. 5. The point(s) where the water is to be abstracted (where the well is to be located), expressed in coordinates. 6 . The form or way of extracting the water, which in most cases will be by mechanical elevation. 7. The nature of the right, i.e., consumptive or non-consumptive use, and of permanent, continuous, discontinuous, or alternating with other persons. 8 . In the case of non-consumptive rights, the point of restitution of the water, the distance between the point of abstraction and the point of restitution, and the difference in elevation between the two must also be indicated [89]. The owner of this right has the possibility to use it freely and benefit from the goods. The state limits itself to a role as "distributor" of water rights on the basis of hydrological data that accounts for the resource stock. Exercising this role as distributor, the state may also, in certain cases, act as "conflict mitigator" (L. 2. Art. 134). De facto, then, water is treated as private property. "Water belongs to its owner who, in accordance with the law, can use, enjoy and dispose of it". (Art. 6) Once acquired, these rights cannot be taken away by state authorities. However, art. 27 of the Water Code gives account of the possibility of expropriating water rights to satisfy "domestic needs" and thus remain with the owner for an unlimited period of time. The owner of the rights can use, trade, or even mortgage water.

A reform in 2005 introduced a compulsory patent payment for those owners who do not or only partially use water resources acquired by legal means. These regulations were established to prevent speculation on prices of water rights (currently the value per liter/second can vary from CLP 1.5 million to 68 million (EUR 1100-61,200) [90] and in view of the drought the country is facing the price may rise even further). The free trading of water rights has deepened the already existing contradictions between a concept of water as a "public good" and as "private property". Water in Chile functions like any other object or resource that can be privatized. Once rights are granted to private owners, they must be registered as "private property" and can then be freely traded in the so called "water market". This water market is free from any interference and influence of the state. Since the 1980s, it has not been as "dynamic" as expected [5,28,87]. Yet, according to some observers, it nevertheless contributes effectively to a more "efficient" water management. As established by the law, users of the same water basin (i.e., holders of this right) must be organized accordingly $[35,85,86]$. In view of the withdrawal of state responsibility, even under today's conditions of water stress, all interested parties, namely the industrial, agricultural, and public sector, compete on equal terms [91]. No priorities are set by the state when granting water rights. This effectively leads to an unfair distribution of this resource as industrial interests are often better organized and resourced and hence more effective in securing water rights in competitive situations. Many critics have argued that human rights are systematically violated by this legislation (today, about $42 \%$ of the rural population has no access to drinking water, which is why in various areas of southern Chile the water supply has to be provided by water cisterns. According to a study by the Amulén Fundation [92], there is a clear correlation between poverty and lack of access to drinking water), but also a general criticism is mobilized against a system interpreted as fundamentally unfair. Advocates argue that the water system is technically efficient and should only be corrected in some respects, such as guaranteeing access to drinking water, which is currently not prioritized in any way [91,93]. 


\section{Ecological Impacts of Water Extraction in Pica, Northern Chile: Presenting the Conflict}

With a coastline of more than four thousand kilometers, Chile has been severely affected by climate change. Impacts are becoming more apparent from year to year. Researchers are already talking about a "mega-drought" that has lasted for more than 10 years $[94,95]$. Our case study comprises two distinct bio-geographical zones in the region of Tarapacá: The Pica Oasis and the Huasco Lagoon (today a salt flat). The distance from the Pica Oasis to Huasco Lagoon is $42 \mathrm{~km}$. Pica and Matilla mark the most populated areas within the commune of Pica. The commune is characterized by geographical features of the Pampa, Altiplano, and Cordillera, ranging from 1250 (Pica, Mantilla) to $5000 \mathrm{~m}$ above sea level. The pampa area is dry and sunny during most of the year, while the altiplano (highland) and cordillera areas are characterized by the phenomenon known as altiplano winter, which lashes them with strong rains during the summer season. The economic activities of the commune are commerce, mining, and agriculture, the latter two being the traditional axes of local economic development in Pica. Tourism is another emerging activity of growing importance [96]. In the Pica oasis, Farmers grow predominantly citrus fruits, using mainly drip irrigation and some ancestral forms such as "flooding". Flood irrigation may not be the most effective method. There are different opinions on this, those who criticize the maintenance of this irrigation technique because of the water that is "wasted" and those farmers who argue that flood irrigation is the only viable alternative for older, deeper-rooted trees. Thus, they argue that if they were to apply the "drip" irrigation technique their trees would die because they are used to the old way. Water is stored in "cochas" (pools), releasing water every 15 to 21 days. Besides recurring droughts, the fragile situation of the oasis is regularly affected by earthquakes, which damage not only the local infrastructure and houses but also the water pipelines of the old irrigation systems. The second key area is the Laguna del Huasco, a salt flat area with 6000 hectares part of the so-called "cuenca del Huasco", surrounded by the Andean Mountains with an altitude of 3800 Meters above the sea level. A salt flat is an endorheic watershed, which, depending on its composition, history, and age, may also contain various types of metals. The salt flat has a high biodiversity despite the extreme temperatures of the Chilean highlands. The primary water controversy in the region centers around the underwater river basins that supposedly connect the highland sector of the Huasco to the Pica oasis.

The conflict broke out between the local community of Pica and the mining company Doña Inés de Collahuasi when the first water rights for the extraction of groundwater in the Huasco Salar were requested in 1988 [97-99]. Approximately $900 \mathrm{~L} / \mathrm{s}$ of water were granted to be extracted from the groundwater flow that feeds the Huasco Salar. The communities in Pica reacted quickly, trying to prevent the granting of the water rights, arguing that the extraction would lead to the drying up of the many areas of the salt flat connected to Huasco, including Pica and Mantilla. However, the hydrological models of the mining company represented the underwater river basin as two separate water basins and argued that the water reserves in Pica and Matilla would not be affected by the water extraction in the Huasco highland sector.

A spokeswoman of one of the largest farming communities in Pica described the fight of the local community. Her story was published in a book of the Observatory of Indigenous Rights [100]. She tells the story how during that process the community had drafted several critical comments that challenged mining company Collahuasi's environmental impact assessment (EIA) on several points. The community argued that the company had made mistakes in its calculations that the consequences of water extraction would allegedly not be felt until 2025. The agricultural leader Susana Guagama reports that the community felt the environmental effects much earlier [100]. Furthermore, the community leader argued that the hydrological models were not able to anticipate the future effects of water extraction [100] (p. 389). She reported that this experience has shown that the process of how hydrological modeling occurred including the lack of opportunity to question assumptions has led to incorrect predictions about the extent and timing of environmental damage $[97,100]$. For this reason, the Collahuasi water extraction is also blamed for the 
deterioration of two other important salt flat areas nearby, Michincha and Coposa. This has been mentioned in several Indigenous consultation processes in which the veracity and scope of the impact studies presented by the mining companies have been questioned. This is also evidenced in the counter reports generated by the communities and their advisors, e.g., in the case of the Aymara community of Coposa in relation to the Collahuasi mine expansion project.

In October 2005, local authorities visited the salt flats to assess the damage with the consequence that the mining companies were held responsible. As a result, their water rights were restricted, and a mitigation procedure was demanded [100]. The case shows how communities need to generate "data" as formally admissible evidence in order to back up and legitimate their expertise, which is grounded in their own everyday ways of life and their experiences, and which is not recognized as such in the formal assessment process. In cases where ecological damage has already occurred, communities have a chance to demonstrate the causal link between extraction activities and damages and thus attribute responsibility. However, in cases where possible detrimental environmental changes are forecast for the future, causality is very hard to establish. A precautionary approach, such as advocated by Guagama, is not foreseen in Chilean impact assessment procedures. The Pica and Huasco communities were successful in articulating their local experience of waterrelated environmental change against the technical expertise of hydrological modeling. Their opposition was successful and currently water is not extracted in Huasco, which is nowadays protected by several international regulations as an important ecological niche. Just like the "Law of National Monuments" in which Huasco has been declared a nature reserve, this means that any form of human influence that could harm this area in any way is prohibited. Since 1996, the area has been protected by Chile's international agreement through the RAMSAR Agreement of the Marshes. In 2002, the former environmental agency CONAMA declared Huasco as an area of "highest priority for the conservation of biodiversity at the regional level." [97,101,102]. Changes have also been made at the legal level: In 1992, protection of wetlands was incorporated through Articles 58 and 63. In this way, approximately 139 wetlands with a surface area of $335 \mathrm{~km}^{2}$ were legally protected until 1996. Nevertheless, applications for water rights in the vicinity of this geographical zone have been made again and again [29] (pp. 357-358).

One might read this case as a relatively successful story of local resistance to an ever-expanding mining industry and the ecological pressures these generate. Yet the case also allows us to discuss a profound asymmetry in the negotiation of hydrosocial territories that relates directly to the procedural frame required by water access regulations. Firstly, current environmental impact assessments occur on the basis of clearly delimited territorial units that follow administrative logics without regard for social and ecological interdependencies between such territorial units. An asymmetry, therefore, arises between territory as governed and territory as lived and experienced by local communities. Secondly, and related, whether a hydrological connection exists between subterranean aquifers that support two different administrative territories is initially unknown. For local communities, this never arose as a problem as they perceived and practiced Pica and Huasco as a single hydrosocial territory. For the mining company, the starting assumption was that aquifers in the two territories were not connected. The hydrological modeling conducted as part of the environmental impact assessment confirmed that initial hypothesis. The second asymmetry arose as local communities had to prove that a connection between aquifers does exist and proof was not accepted on community terms but had to be brought forth in the form of supposedly neutral science-a form of articulation not readily available at the communities' disposal. We now turn to the analysis of empirical material that shows in more detail how exactly local communities struggle against these asymmetries in attempts to rearticulate their matters of concerns as matters of fact [103]. We emphasize the role of uncertainty in this process and how it enabled a plurality of views to emerge on drivers of water stress in the region. 


\section{Divergent Explanations and Possible Causes of the Regional Water Stress}

During periods of "extraordinary drought", the Chilean central government can declare temporary exceptional situations of water shortage $[93,104]$. In a water-scarce area such as the Atacama Desert [73], this occurs regularly, and the industry is aware of it [36]. In 2019, about 17 exceptional decrees were issued in Chile due to water stress situations. The criteria for this exceptional situation are based purely on "physical characteristics and on hydro-meteorological conditions, such as rainfall, river flows, reservoir quantities and the condition of the water basins", which are measured using technical methods that completely disregard the human impact on their environment [93] (p. 124). In 2020, around 18 decrees of water shortage in various regions of the country have been declared. In an interview with one of the heads of the Community Relations Department of the Collahuasi Company, the manager described the general impact of mining:

"The water issue is a one-off situation, in which this extractive mining industry uses large volumes and has water rights, but we must also see that at the national level, the percentage of water use of these large companies is minimal compared to other industries. And here it is reflected, because, obviously, we are in the northern sector, the desert, where the issue of water is the main one."

Comparing water use between sectors at a national level does show that mining uses only a fraction of the amount consumed by agriculture. This fact is often highlighted by managers to demonstrate the minimal impact this industry has on water. Through the registers of water rights granted by the DGA, it is possible to observe the distribution patterns in the region: The mining company D.S.I. de Collahuasi started requesting water rights in 1985. From then on, rights were repeatedly granted to the mining company (1985, $1991,1994,1998,1999,2002,2003,2005,2007)$. The other two largest copper producers in the region, Cerro Colorado (1982) and Quebrada Blanca $(1991,1995)$, also appear in the register. However, as it was already pointed out, there are conflicting views on the responsibility of mining in relation to the current water stress situation. Specific environmental impacts of mining, such as the drying up of the Michincha and Coposa Lagoons by Collahuasi and the environmental impacts in Lagunilla Lagoon by Cerro Colorado (BHP), are nevertheless not associated with the general water stress situation in Tarapacá. Here one can notice clear diverging views between authorities, mining companies, and the local population. While this holds true at a national level, the mining industry is well aware that in the relevant regional contexts and their activities often make them the major user of water, driving local and regional water resources towards critical boundaries [105]. There is much evidence that the mining industry is under pressure both nationally and internationally to generate "ecologically sustainable" mining $[36,106,107]$. It does this by adopting standards such as ISO 26000, commitments to a CSR policy, and promoting community relations with Indigenous peoples [108]. Mining companies are becoming sensitive to impacts on groundwater levels and are pushing desalination as a technical solution to water stress [36]. However, in the interviews and conversations with people living in the related areas close to the mining sites, people are blaming mining for the regional water stress that they are experiencing. Numbers cited by company management indicate other possible explanations for the situation. As is so often the case in extractivist conflicts, companies are fostering a discourse that frames accusations of mining-related water stress as unreasonable fears of "unskilled" people who do not trust the hydrological modeling. In Chile, companies know the state is on their side, as the allocation of water rights is made on the basis of predictions from hydrological models alone. Models represent the characteristics of the aquifers and thus form the basis for decision-making. The state and the companies neither see a need nor do they have incentives for making the (underground) territory legible in any other way but through model predictions.

When asked about the water rights in Pica, the director of the Water directorate (DGA) in Tarapacá said: "When we deliver water rights, we analyze all these factors and, obviously, we establish a limit of granted rights so that this imbalance that exists is sustainable for the aquifer over time ..." ". Yet, he also acknowledged problems associated 
with the assessment of the aquifers and thus with the water rights allocation process: " .. because of the technical information that was available at that time, it was believed that the volume stored was bigger. Finally, with a dozen studies that we have carried out, we are much clearer about the reality of the aquifer. And that is why we have decreed the Pampa as a "restricted area", and we already know that there was an over-allocation of rights".

In the end, the official explained that the DGA granted more water rights than they should have, thus contributing to water stress in the region. Knowledge production, he reflected, especially in a field of research as hydrology, is costly and difficult to carry out. The lack of financial resources and expertise are recognized by state agencies such as the DGA. While state officials recognize the relatively clear evidence that water rights exceed the recharge capacity of the affected aquifers, they cannot revoke rights once they have been issued to companies despite new evidence changing the original assessment. This situation leads companies to opt for strategies based on corporate responsibility, as is the case for the relevant mining company Quebrada Blanca, which has offered to return some of their water rights once they start operating with desalinated water. In the absence of other measures, the state and the people depend on companies' voluntary commitments.

Other factors need to be considered. The Pica Oasis is the only non-urban area in the region that grows in population According to comparative data from the 2002 and 2017 census, the Pica district has grown by 50\%, with a population of 6178 in 2002 and 9296 in 2017. However, this data is valid for the larger commune of Pica, which includes several villages. Even so, the localities of Pica and Matilla (both oases) are the most inhabited places of the district [96]) and people and local authorities are aware of that. This also exacerbates the demand for groundwater in an area with small-scale agriculture as its main source of income, apart from mining. Interviews with state officials clearly indicate that they also see responsibility for water stress with farmers illegally abstracting water for agriculture:

"If you look at satellite images of Pica in recent years, you realize that there are more and more crops, but we don't constantly give away water rights. In other words, if we compare the water rights with the green area, we could indeed identify one of the strategies for monitoring Pica. But there are areas of the green areas with no water rights given (sic), and it is probable that these waters come from illegal wells."

This idea can be contrasted with the understanding of farmers and community leaders who live and work in Pica. One of them mentioned that if this thesis of illegal wells were true, the cultivated farms would reach as far as Pozo Almonte (a town $52 \mathrm{~km}$ far from Pica). Another local leader mentioned that the more significant problem in Pica is that the oasis was growing "inorganically", i.e., in an uncontrolled way. Land parcels are sold and houses with swimming pools are built for wealthy people who live in other parts of the region and come to the oasis on holiday or for recreation. This brief analysis already shows that the conflict around water stress, its potential drivers, and associated responsibilities is a complex and deeply political debate not only about water but also about the question of what the future holds for the Pica Oasis. Who determines its pathway into the future, and, ultimately, who benefits and who loses out? Within this complex debate, the question of whether the two aquifers are connected or not remains unresolved. However, this issue continues to dominate the debate and it is strongly framed in scientific terms of environmental impact assessments and hydrological models. This depoliticizes decision-making processes, which is one of the aspects that the notion of hydrosocial territories highlights: "Contrasting such a conception, which is often used as a veil to legitimize deeply political choices that protect and stabilize specific political orders, we call for a repoliticization, that is the recognition of the political nature, of hydrosocial territories through the study of everyday water use praxis" [40] (p. 2). If environmental concerns are framed and expressed only in terms of technical language, the conflicts are already framed in specific terms that struggle to reflect the range of issues at stake. Aquifer extensions and dynamics are uncertain, lived and experienced through different water practices $[28,53,54]$, and not all human experience seems to translate well into technical terms. 


\section{Local Visions Contesting Water Management}

Although the water extraction occurs mainly in the highlands, the inhabitants of the low mountain areas seem to feel an increasing uneasiness that sooner or later they will run out of water. Previous experiences of this kind are still very much in people's minds, such as the desiccation of the Quisma Valley whose main aquifers were expropriated in the first decades of the 20th century [109]. When this water source dried up, people had to leave the valley. Some families living in Pica came from the Quisma Valley and now hope that this story will not repeat itself. These issues have been mentioned by people living in the oasis and many insist on the aquifer connection. As one Indigenous leader in Pica explained, "we are not experts, but we do understand that this overexploitation sooner rather than later will affect us $(\ldots)$ there are sectors in Pica that have already been seen to be dry." Another Indigenous woman spoke about their own judgment of the impacts of water extraction: "They (Collahuasi) said they were extracting a minimum number (liters) per second. So, we said how is it possible that with what you take out, (the aquifer) is already drying up. It is absurd. Everybody knows that they take out a tremendous amount (of water) per second. They say, no." In several conversations, people expressed their mistrust towards the mining companies' communication with respect to both the amount and the location of extraction. What the state requires from the companies through its policies local communities feel is not enough to protect the ecology of the area. Local farmers explain how they worry that impacts will not be felt today but that they are sure to appear in 30 to 50 years. To them, it only seems a question of time as they already experience landscapes around them changing. Take the case of a mine worker, who has lived in the Pica sector, talking here about his perception of environmental change in the Huasco Lagoon:

"When I was a boy, I used to go there, and I was about 10 years old, ( . . ) it was a lagoon (... ) And now you see, it's a salt flat. (...) And in some places, you see some pools of water. So of course, they can tell me a lot of things, but among all those things they can tell me, you know what, the mining companies may be taking water from higher up and it affected here. That can also be a factor." Further: "So two factors come together and converge: the demographic explosion and the water resource. And here we have to put a stop to the issue, because Pica cannot grow any more if it does not have water resources. So, there is a whole issue here. The mining company is being blamed."

According to the miner's analysis, people blame the company, but other factors that are not the responsibility of the company must also be taken into account. For years, the mining companies have been investing in projects for the people in Pica. In this way, their material dependence generates a situation that is expressed in their ambivalence when it comes to looking for culprits. These multiple considerations vary among the different actors, depending on their knowledge, livelihood, and appreciations of the transformation of the local ecology. These contribute to their critical valuations regarding the impacts of mining, but also take into account the effects of climate change in these regions. People become aware of the multiple factors that contribute to the problem. Yet whether the aquifers are communicating vessels or separate water bodies remains highly uncertain and contested [42,50], a situation of which the State Authority responsible for water management (DGA) is clearly aware. As their director explained: "You have to separate the concepts a little. To demonstrate if there is a connection between the aquifers. (...) It is super complex because there may indeed be a connection, but technically you can't prove it. Because this connection is very underground, maybe it has very slow rates of input. And you have to think that the hydrogeology of an aquifer is (... ) empirical too. It's like the "hydro fantasy" that hydrogeologists call it. And it has a model that explains a certain reality, but as we know, the models are very simple explanations of reality".

Technically speaking, even the DGA is currently unable to prove or disprove the aquifer interconnections because of its lack of hydrological expertise and financial resources. Nonetheless, this not only accounts for the asymmetry between the knowledge in dispute but also in the tension of a relation that amalgamates expert knowledge, socio- 
territorial configurations, legibility of resources, administration, management, and distribution through water rights and commodification $[5,110,111]$. Given prevailing uncertainty, the conflict cannot be resolved only at a technical level, hence other factors start to come in. However, decisions are made based on available information and despite uncertainties. The lack of public resources to provide further assessments and broader evidence reflects central government priorities. It confirms that it is by and large private companies that estimate and characterize the ecological relations that their extractive practices transform-as well as the uncertainties associated with it. As many researchers have already pointed out, in a neoliberal economy based on the extraction of "strategic" natural resources, responsibility is transferred to the private sector $[5,29,42,50,55,112]$.

Another vital issue is the "material" availability of water in a shifting environment impacted by climate change $[85,86]$. In Chile, these concerns are expressed in the discussion of whether each river basin should be managed in its own specific way, respecting its local ecological conditions $[46,93,113]$. Such a shift would lead to significant legal consequences affecting the central water administration based on the water code of 1981. The notion of the hydrosocial territory serves the analysis of this discrepancy between administrative and ecological "units" as it can show how disputes between territories take place at multiple levels: technical, socio-environmental, political, and legal. Undoubtedly, stark differences exist in the opinions and assessments of local communities, authorities, and mining companies. Some of these differences even seem incommensurable with each other regarding practices translated into technical knowledge [114]. However, as decisions have to be legitimized on techno-scientific grounds, as a state official explained, decisions are made based on available data and hydrological models. This is also in line with the administrative division of different water flow basins:

"Then there may indeed be aquifers that have connections that are unknown today. It may be. But there is another issue that has to do with the fact that the DGA recognizes these aquifers as hydrogeological sectors of common use, that is, they are sectors that interact with each other. For example, the Pica aquifer and the Pampa del Tamarugal aquifers are hydrogeologically connected, but they function as totally different units, so the DGA administratively separates them. You have the Pampa aquifer and the Pica aquifer. There is a hydrogeological connection, there is indeed. But they function as different hydrogeological sectors of common use. If I pump,-being very exaggeratedone thousand (liters) out of the Pampa del Tamarugal (aquifer), I probably won't have a direct effect on Pica."

Chilean water management provides the technical provisions and criteria through which water storage is made visible, quantified, managed, and distributed. The so-called "groundwater regulation" of 2004 gives clear indications about the conditions for applying for groundwater extraction, e.g., art. 20: if (c) there is availability of groundwater in the hydrogeological sector of common use; (d) that the exploitation is adequate for its conservation and long-term protection, considering the technical background of irrigation and discharge, as well as existing and foreseeable conditions. The crux here is that the decision to grant water rights is based on an assessment of the "foreseeable conditions". These, however, come with significant uncertainties. It is the administrative decision whether to consider aquifers and river basins in the region as "separate units", which lowers the range of uncertainty, making the impacts seemingly easier to predict and monitor. It is the administrative decision that turns a highly dynamic, fluid, and indeterminate system into a rather static and manageable resource. Water here can be considered a resource with extraction granted, because a dynamic system becomes legible to the state as a network of static units. While this looks like a decision based on hydrogeological evidence, what is to be considered "evidence" and scientific "facts" is preconfigured by political and legal decisions in the first place [46,115]. Scientific representation in the form of models seems to play on neutral ground, as if it protected from the "realm of politics" [103], yet modeling here does not function as a heuristic tool. Rather, modelling is preconfigured in an administrative frame and thus assists in the production of evidence that ultimately 
leads to and legitimizes decisions regarding the management of a specific hydrosocial territory. In this way, modeling inadvertently reduces troubling uncertainties in favor of making a hydrosocial territory clearly legible without any ambiguities. Modeling, in this context, necessarily becomes political. It shapes powerful images of reality and has "particular socio-economic effects because particular choices, knowledge, preferences, and 'naturalized discourses' have 'materialized' in the model" [60] (p. 1436).

Of course, another way of broadening the evidence base and appreciating uncertainties might have been to allow non-technical knowledge to be included. It is precisely because "the socio-hydrological model itself becomes a political 'actor' that is socially constructed and therefore not neutral in its effect on the socio-hydrological reality" [60] (p. 1435) that modeling ought to attempt to integrate local stakeholders' perspectives [59,82]. Our paper has shown how local people indeed try to articulate their concerns vis-à-vis the regulatory constellation - or be it in a rather uncoordinated process. Importantly, however, this articulation does not impress the local official: For even if the supposed connections between aquifers did "indeed exist", this would not matter to the hydrological management process. Reports of the possibility of aquifers being connected fail to be considered as evidence. This can happen, because objectified knowledge framed in law can never be simply "applied" to real-world situations without people exercising discretion: "What people do when invoking the law or facing legal difficulties is never law as such. People interact with, and help to maintain or transform, various legal complexes-ill-defined, uncoordinated, often decentralized sets of networks, institutions, rituals, texts, and relations of power and of knowledge that develop in those societies in which it has become important for people and institutions to take a position vis-a-vis law" [115] (p. 10). In the same way that models do not simply represent reality, law is not simply applied to reality. Rather, it is through discretion that a legal complex manifests itself and the legal complex in our case study-shaped by an extractivist history, neoliberal politics, hydrogeological models, local officials, and concerned communities articulating their concerns-produces water in the region as a resource by systematically not recognizing alternative hydro-social territories.

People know that expert knowledge and scientific models are describing impacts, projecting them into possible futures, making predictions. However, as the above story points out, people have often been living in the region for a long time. Given that the region is mostly desert, people are attentive to water as a means of sustaining life and they observe, experience, and know changes that have taken and are taking place in their own ways. People and community discourse represent the aquifers as "communicating vessels" and this shapes distrust towards the company's attempt to separate into two what they consider a single territory. This distrust fuels growing uncertainty with respect to a sustainable future of local livelihoods.

Local communities' responses to the mining expansion are based on direct experiences of the local environment and empirical observations, bringing out substantial fears related to the sustainability of water supplies. Within official assessments and mining company discourse, these experiences are framed as emotional responses vis-à-vis the scientific facts that hydrological modeling provides. In the Chilean environmental regulations, the civil population has the possibility to give their comments, observations, and criticisms to the projects that enter the environmental evaluation system. These must be answered by the companies' "owners" of the projects under review. The observations and reports can be followed on the website of the Chilean government's environmental evaluation system (www.sea.cl, accessed on 3 December 2021). In fact, these reports are elaborated by Indigenous communities and their advisors. The issue of water is one of the most criticized points regarding the possible impacts of mining on a given territory. Here, aspects of Chilean law come into consideration that define what an "area of impact" is, i.e., it implies its geographical circumscription, which often does not correspond to the understanding of the territory by the Indigenous and non-Indigenous communities themselves. Something similar occurs regarding theoretical limitation of underground river basins. 
It in this context, that one of the local communities in Pica presented various data, evidence, and documents to the authorities to support their view. A spokesperson asked: "What other evidence do they want?" [100] (p. 390). In other words, what kind of knowledge is necessary to be taken seriously? If the legal framework and regulatory process seem to play in favor of the companies, how then can local people present their concerns about extractive policies and practices in legitimate ways? This articulates an existing gap between different knowledge systems and different values [114]. Yet in Chile, "earth and environmental sciences play an important role in producing environmental knowledge that is generally perceived to be technical, accurate and unbiased, and therefore reliable. Such knowledge is often deemed crucial for informing environmental assessments and policy-making" [50] (p. 418). The hegemony of these specific forms of knowledge and evidence means that, for example, ancestral water practices are systematically undermined by seemingly objective evidence recognized by central water management $[4,28,38,54]$. The problem here is that the regulatory perspective on what makes expert knowledge technically sufficient and thus legitimate in an administrative process is not shared by the local communities. Hydrological models fail to lead to a sense of shared ownership with regards to the long-term environmental impacts of water extraction. Instead, feelings of uncertainty prevail, deeply rooted in local experiences and failed projections of environmental impacts [72,76]. However, as we have already noted, the problem has more to do with the application of certain models and the use of modeling outcomes rather than the models themselves in a generic sense. There have already been several experiences that demonstrate that different knowledges can enter a fruitful dialogue through participatory modeling that provides greater stability, legitimation, and robustness to applied knowledge [59-61].

\section{Conclusions}

The different means of dealing with the alleged connection between aquifers demonstrate how the current water governance regime aligns a neoliberal legal setting with technical evidence provided by hydrological models to produce one specific hydrosocial territory $[38,40,41,48,49]$. Others, such as ancient water management practices, different ways of dealing with uncertain futures, and wider notions of knowledge and expertise are not only not recognized or "seen" they are also rendered latent in this controversy over water use [53-55,111]. This epistemological conflict, i.e., a conflict over legitimate ways of knowing hydrological dynamics today and in the future, points to a more fundamental ontological dimension of this conflict: Particular ways of knowing render specific livelihoods, uncertainties, and water practices viable in hydro-social territories while denying others.

Our case shows that hydrological models are far from being neutral devices of technical knowledge, they become actors "in themselves" [60]. People who appreciate the production of this kind of "evidence" are suspicious of the reliability and truthfulness of this evidence presented as "facts". In its most drastic form, this suspicion leads people to understand hydrological models as captured and instrumentalized "visions" according to very specific economic interests. In other cases, they are simply seen as "wrong", as local communities insist on precaution in their plea for more sustainable and responsible state institutions and mining companies.

In neoliberal Chile, governments have always favored private water management. Yet our case study demonstrates the tensions inherent in the private management of a common good [116], how water can be meaningfully considered a public entity $[5,32,93,104,117]$, and how these debates affect environmental justice [33,34]. We have shown how resource extraction always implies some "messiness" [118] as private companies align with legal complexes and scientific evidence to exploit in very specific ways what is considered a common good $[4,29,30]$. In countries developing such as Chile, resource extraction is a key feature of the country's positioning in global markets as a rent economy. Water management is considered part of the key infrastructure underpinning economic development and political decision-making. 
We take three messages away from this case analysis: First, the perpetuation of environmental injustices is systemic insofar as its structural drivers lie deeply embedded within the neoliberal infrastructures of national legislation, failures to hold private companies responsible, lack of balanced forms of exercising regulatory discretion at local level, and local and Indigenous communities' inabilities to articulate their concerns in legitimate forms. There is no silver bullet as changes on all levels of governance need to work together to enact an altogether different logic of extractive practices. Only such systemic change stands a chance to level the playing field within which alternative hydrosocial territories can compete fairly and under conditions of transparency and due process. Second, hard scientific evidence is often understood as a neutral ground from which to cut fairly through heavily politicized configurations and contested understandings of local hydrosocial conditions. Our analysis shows, however, how scientific knowledge production becomes deeply politicized in the everyday life of water conflicts. It is the law's dream of neutral scientific knowledge that strengthens the structural coupling of legislation and hydrologic and earth systems knowledge. The rules according to which knowledge is admitted as evidence and the uneven distribution of resources for knowledge production stack the cards against wider ecologies of expertise and knowledge claims outside of narrow readings of evidence. It is an important task for hydrosocial research to further develop participatory modeling formats and transdisciplinary research frameworks. Employed in long-term research presences in regions shaped by extractive conflicts, such efforts can help to restore scientific knowledge practices as arbiters of public and democratic reason. They can help to broaden the ecologies of expertise within which hydrosocial territories take shape and to accommodate complex and uncertain developments in more productive ways. Third, as we write, Chile is entering the second round of presidential elections and working towards a new constitution which may readdress some of the starkest neoliberal biases in favor of a more public management of resources. This might bring a degree of the systemic change we have identified as important. However, this is far from being a matter of Chilean politics alone. The echoes of colonial dependence in today's elitist forms of governance, the massive constraints exercised through global supply changes delivering resource security to developed economies particularly in the Global North, and the short-term project-based nature of (hydrosocial) research engagement in such centers of extractivism all help to set the stage on which the crucial dispute over the dis/connection of aquifers plays out.

Author Contributions: Conceptualization, S.M.C.P. and J.N.; methodology, S.M.C.P.; software, S.M.C.P.; validation, S.M.C.P. and J.N.; formal analysis, S.M.C.P. and J.N.; investigation, S.M.C.P.; resources, S.M.C.P.; data curation, S.M.C.P.; writing-original draft preparation, S.M.C.P. and J.N.; writing-review and editing, S.M.C.P. and J.N.; funding acquisition, S.M.C.P. All authors have read and agreed to the published version of the manuscript.

Funding: This article has been written in the context of a doctoral research funded by the National Agency for Research and Development (ANID), Government of Chile. The scholarship was granted to Cornejo and runs from 2018 to 2022.

Institutional Review Board Statement: The study was conducted according to the guidelines of the Declaration of Helsinki and followed the ethical guidance of the American Anthropological Association for fieldwork. Ethical review and approval were waived for this study due to its noninvasive nature and ethnographic work with consenting adults only.

Informed Consent Statement: Informed consent was obtained from all subjects involved in the study.

Data Availability Statement: Data comprises fieldnotes and transcripts from interviews and informal conversations. Due to privacy concerns, the data are not publicly available for secondary use. Please contact the authors to discuss access on an individual case basis.

Acknowledgments: We thank all our informants and interview partners for their kind cooperation and support of this study.

Conflicts of Interest: The authors declare no conflict of interest. 


\section{References}

1. Astorga, R. Gobernanza E Institucionalidad Ambiental En Chile: Cómo Inciden En El Crecimiento Económico; CIEPLAN: Santiago, Chile, 2019.

2. Comisión Chilena del Cobre (COCHILCO). Inversión En La Minería Chilena-Cartera De Proyectos 2021-2030; COCHILCO: Santiago, Chile, 2021.

3. Observatorio Latinoamericano de Conflictos Ambientales (OLCA). Agua y Extractivismo: Una mirada desde las Comunidades. Memoria Encuentro AguAnte La Vida; Observatorio Latinoamericano de Conflictos Ambientales: Santiago, Chile, 2013.

4. Yáñez, N.; Molina, R. Las Aguas Indígenas en Chile; LOM Ediciones: Santiago, Chile, 2014.

5. Bauer, C. Contra la Corriente. Privatización, Mercados de Agua y el Estado en Chile; LOM Ediciones: Santiago, Chile, 2002.

6. Gutiérrez, A.; Silva, G.; Guzmán, J.; Ibaceta, G.; Schuster, J.P.; Tapia, F.; Droguett, E.R.; Nuñez, J. Escasez Hídrica en Chile. Desafíos Para el Consumo Humano y Perspectivas en Modelos Comparados; Fundación Newenko: Santiago, Chile, 2019.

7. Gunder Frank, A. El Desarrollo del Subdesarrollo; Pens. Crít. N. 7: Habana, Cuba, 1967; Available online: http:/ /sgpwe.izt.uam. $\mathrm{mx} /$ files/users/uami/nivon/GUNDER_FRANK_desarrollo_del_subdesarrollo.pdf (accessed on 20 May 2019).

8. Escobar, A. Encountering Development. The Making and Unmaking of the Third World; Princeton University Press: Princeton, NJ, USA, 1995.

9. Sachs, W. Planet Dialectics. Explorations in Environment E Development; Zed Books: New York, NY, USA, 2015.

10. Boccardi, F.; Giovannini, S.; Orellana, M.; Rochietti, D. El sueño minero: Un análisis de la narrativa utópica del desarrollo" Perspectivas de la comunicación. Perspect. De La Comun. 2008, 1, 56-72.

11. Zapata, F.A. Neoliberalismo y crisis económica: Políticas estatales, mercado y agricultores en Chile, 1973-1985. Hist. Crítica 2016, 62, 119-139. [CrossRef]

12. Caputo, O.; Galarce, G. La Crisis de la Economía Chilena y los Errores del Neoliberalismo; Universidad ARCIS: Santiago, Chile, 2000; Available online: https://www.archivochile.com/Ideas_Autores/galarceg/galarceg0003.pdf (accessed on 11 February 2020).

13. Mc Evoy, C. Guerreros Civilizadores. Politica, Sociedad y Cultura en Chile Durante la Guerra del Pacífico; Universidad Diego Portales: Santiago, Chile, 2011.

14. Tudela, P. El Estado y Sociedad Chilena ante los Aymaras de Tarapacá (1era Región de Chile): Factores y Consecuencias de su Integración Entre 1930-1973; Documento preparado por Patricio Tudela Poblete, por encargo del Subgrupo de Trabajo Pueblo Aymara, Grupo de Trabajo Pueblos Indígenas del Norte, de la Comisión de Verdad Histórica y Nuevo Trato; Comisión de Verdad Histórica: Santiago, Chile, 2002.

15. González, S. El poder del símbolo en la chilenización de Tarapacá. Violencia y nacionalismo entre 1907 y 1950. Rev. de Cs. Soc. 1995, 5, 15.

16. Loveman, B. Chile. The Legacy of Hispanic Capitalism; Oxford University Press: New York, NY, USA, 1988.

17. Acosta, A. Extractivism and neoextractivism: Two sides of the same curse. Bey. Dev. 2013, 1, 61-86.

18. Gudynas, E. Diez tesis urgentes sobre el nuevo extractivismo. Contextos y demandas bajo el progresismo sudamericano actual. In Extractivismo, política y sociedad; Centro Andino de Acción Popular (CAAP), Centro Latinoamericano de Ecología Social CLAES/CAAP: Quito, Ecuador, 2009; pp. 187-225.

19. Gudynas, E. Modos de Producción y Modos de Apropiación una Distinción a Propósito de los Extractivismos. In El Sociometabolismo del Capital y la Depredación de la vida. Debates Sobre el Extractivismo; Lom: Santiago, Chile, 2016; pp. 95-122.

20. Bebbington, A.; Bornschlegl, T.; Johnson, A. Political Economies of Extractive Industry: From Documenting Complexity to Informing Current Debates. Dev. Chang. 2013. [CrossRef]

21. Antonelli, M. Minería Transnacional y Dispositivos de Intervención en la Cultura. La Gestión del Paradigma Hegemónico de la "Minería Responsable y Desarrollo Sustentable". In Minería Transnacional, Narrativas del Desarrollo y Resistencias Sociales/Edición a Cargo de Maristella Svampa y Mirta A; Biblios: Buenos Aires, Argentina, 2009; pp. 51-100.

22. Antonelli, M. Formaciones predatorias. Fragmentos de un Prisma bio (Tanato) Politico Sobre Extractivismo y Capitalismo Contemporáneo. In El Sociometabolismo del Capital y la Depredación de la Vida. Debates Sobre el Extractivismo; Lom: Santiago, Chile, 2016; Volume 20, pp. 155-180.

23. Antonelli, M.; Svampa, M. Minería Transnacional, Narrativas del Desarrollo y Resistencias Sociales; Biblios: Buenos Aires, Argentina, 2009.

24. Machado, H. Agua y Minería Transnacional. Desigualdades hídricas e implicaciones biopolíticas. Habitat Urbano 2010, 9, 61-90.

25. Machado, H. Crítica de la razón progresista. Una mirada marxista sobre el extractivismo/colonialismo del siglo XXI. In Naturaleza Americana. Extractivismo y Geopolitica del Capital; Lom: Santiago, Chile, 2015; Volume 19, pp. 137-174.

26. Svampa, M. Consenso de los commodities, giro ecoterritorial y pensamiento crítico en América Latina. OSAL 2012, 13, 15-38.

27. Svampa, M. Extractivismo, desarrollo y buen vivir. Visiones en pugna. In El Sociometabolismo del Capital y la Depredación de la Vida. Debates Sobre el Extractivismo; Lom: Santiago, Chile, 2016; Volume 20, pp. 181-204.

28. Prieto, M. Privatizing Water in the Chilean Andes: The Case of Las Vegas de Chiu-Chiu. Mount. Res. Dev. 2015, 35, 220-229. [CrossRef]

29. Barros, A. Agua subterránea: Derechos colectivos, autonomía, mercado y justicia ambiental en el territorio Lickanantay (desierto de Atacama, Chile). In Globalización, Derechos Humanos e Indígenas; Bello, Á., Aylwin, J., Eds.; Observatorio de Derechos de los Pueblos Indígenas: Temuco, Chile, 2008; pp. 347-373.

30. Barros, A. The Fetish Form of Law: Water, Atacama Desert People and the Extractive Industry (1994-2010); Iinstitut d'études avancees de nantes, Rencontres scientifiques: Nantes, France, 2012; pp. 6-10.

31. Yáñez, N.; Molina, R. La Gran Minería y los Derechos Indígenas en el Norte de Chile; LOM: Santiago, Chile, 2014. 
32. Budds, J.; Hinojosa, L. Las industrias extractivas y los paisajes hídricos en transición en los países andinos: Análisis de la gobernanza de recursos y formación de territorios en Perú. In Agua, Injusticia y Conflictos; Isch, E.L., Boelens, R., Peña, F., Eds.; PUCP-IEP-CBC: Lima, Peru, 2012; pp. 45-63.

33. Boelens, R.; Cremers, L.; Zwarteveen, M. Justicia Hídrica: Acumulación, Conflicto y Acción Social; IEP-PUCP: Lima, Peru, 2011.

34. Boelens, R.; Peña, F.; Isch, E. Agua, Injusticia y Conflictos; PUCP-IEP-CBC: Lima, Peru, 2012.

35. World Bank. CHILE. Diagnóstico de la Gestión de los Recursos Hídricos. Departamento de Medio Ambiente y Desarrollo Sostenible. Región para América Latina y el Caribe; World Bank: Washington, DC, USA, 2011.

36. COCHILCO (Comisión Chilena del Cobre). Proyección de Consumo de Agua en la Minería del Cobre al 2026. Available online: https:/ /www.cochilco.cl/Listado\%20Temtico/2\%2023\%20Proyeccion \%20de\%20consumo\%20de \%20agua \%20en \%20 la\%20mineria\%20del\%20cobre\%202016-2027.pdf (accessed on 3 June 2021).

37. Acosta, O. Water and Mining. In Water Policy in Chile; Donoso, G., Ed.; Global Issues in Water Policy' Series; Springer: Berlin, Germany, 2018; pp. 179-196.

38. Boelens, R. Cultural politics and the hydrosocial cycle: Water, power and identity in the Andean highlands. Geoforum 2014, 57, 234-247.

39. Perreault, T. Las contradicciones estructurales y sus implicaciones para la justicia hídrica: Pensamientos incompletos. In Justicia Hídrica: Acumulación, Conflicto y Acción Social; Boelens, R., Cremers, L., Zwarteveen, M., Eds.; Fondo Editorial PUCP: Lima, Peru, 2011; pp. 71-83.

40. Boelens, R.; Hoogesteger, J.; Swyngedouw, E.; Vos, J.; Wester, P. Hydrosocial territories: A political ecology perspective. Water Int. 2016, 41, 1-14. [CrossRef]

41. Swyngedouw, E. The Political Economy and Political Ecology of the Hydro-Social Cycle. J. Contemp. Water Res. Educ. 2009, 142, 56-60. [CrossRef]

42. Budds, J. Power, Nature and Neoliberalism: The Political Ecology of Water in Chile. Singap. J. Trop. Geogr. 2004, 25, 322-342. [CrossRef]

43. Latour, B. Llamada a revisión de la modernidad. Aproximaciones antropológicas. In Technogénesis. La Construcción Técnica de las Ecologías Humanas; Criado, T.S., Ed.; AIBR: Madrid, Spain, 2008; Volume 2.

44. Haraway, D. Ciencia, Cyborgs y Mujeres. La Reinvención de la Naturaleza; Cátedra: Madrid, Spain, 1995.

45. Linton, J. What Is Water? The History and Crisis of a Modern Abstraction; Carleton University: Ottawa, ON, Canada, 2007. [CrossRef]

46. Prieto, M.; Bauer, C. Hydroelectric power generation in Chile: An institutional critique of the neutrality of market mechanisms. Water Int. 2012, 37, 131-146. [CrossRef]

47. Latour, B. Give Me a Laboratory and I will Raise the World. In Science Observed: Perspectives On the Social Study of Science; Cetina, K.K., Mulkay, M., Eds.; Sage: London, UK, 1985; pp. 141-170.

48. Mills-Novoa, M.; Boelens, R.; Hoogesteger, P.; Vos, J. Governmentalities, hydrosocial territories \& recognition politics: The making of objects and subjects for climate change adaptation in Ecuador. Geoforum 2020, 115, 90-101. [CrossRef]

49. Hommes, L.M.; Boelens, R.; Duarte- Abadía, B.; Hidalgo-Bastidas, J.P.; Hoogesteger, J. Reconfiguration of Hydrosocial Territories and Struggles for Water Justice: From Part II-Hydrosocial De-Patterning and Re-Composition (Ch. 8). In Water Justice; Boelens, R., Perreault, T., Vos, J., Eds.; Cambridge University Press: Cambridge, UK, 2018; pp. 151-168.

50. Budds, J. Contested $\mathrm{H}_{2} \mathrm{O}$ : Science, policy and politics in water resources management in Chile. Geoforum 2009, 40, 418-430 [CrossRef]

51. Bauer, C. Slippery Property Rights: Multiple Water Uses and the Neoliberal Model in Chile, 1981-1995. Nat. Res. J. 1998, 38, 109-155.

52. Bauer, C. Water Conflicts and Entrenched Governance Problems in Chile's Market Model. Water Altern. 2015, 8, 147-172.

53. Prieto, M.; Salazar, D.; Valenzuela, M.J. The Dispossession of the San Pedro de Inacaliri River: Political Ecology, Extractivism and Archaeology. Extr. Ind. Soc. 2019, 6, 562-572. [CrossRef]

54. Babidge, S.; Bolados, G. Ritualidad y extractivismo: La limpia de canales y las disputas por el agua en el salar de Ataca- Norte de Chile. Estud. Atacam. 2017, 54, 201-216.

55. Bolados, G.; Henríquez, F.; Ceruti, C.; Sánchez, A. La eco-geo-política del agua: Una propuesta desde los territorios en las luchas por la recuperación del agua en la provincia de Petorca (Zona central de Chile). Rev. Rupturas. 2018, 8, 159-191. [CrossRef]

56. Hoogendam, P. Hydrosocial territories in the context of diverse and changing ruralities: The case of Cochabamba's drinking water provision over time. Water Int. 2019, 44, 129-147. [CrossRef]

57. Sanchez-Plaza, A.; Broekman, A.; Retana, J.; Bruggeman, A.; Giannakis, E.; Jebari, S.; Krivograd-Klemencic, A. Participatory Evaluation of Water Management Options for Climate Change Adaptation in River Basins. Environments 2021, 8, 93. [CrossRef]

58. Laurita, B.; Castelli, G.; Resta, C.; Bresci, E. Stakeholder-based water allocation modelling and ecosystem services trade-off analysis: The case of El Carracillo region (Spain). Hydrol. Sci. J. 2021, 66, 777-794. [CrossRef]

59. Torso, K.; Cooper, C.M.; Helkey, A.; Meyer, C.; Kern, A.L.; Wardropper, C.B. Participatory research approaches in mining impacted hydrosocial systems. Hydrol. Sci. J. 2020, 65, 2337-2349. [CrossRef]

60. Melsen, L.A.; Vos, J.; Boelens, R. What is the role of the model in socio-hydrology? Discussion of "Prediction in a socio-hydrological world". Hydrol. Sci. J. 2018, 63, 1435-1443.

61. Rangecroft, S.; Birkinshaw, M.S.; Rohse, R.; Day, L.; McEven, E.; Makaya, Y.A.F. Van Loon. Hydrological modelling as a tool for interdisciplinary workshops on future drought. Prog. Phys. Geogr. Earth Environ. 2018, 42, 237-256. [CrossRef] 
62. Bots, P.W.G.; Bijlsma, R.; Von Korff, Y.; Van der Fluit, N.; Wolters, H. Supporting the Constructive Use of Existing Hydrological Models in Participatory Settings: A Set of "Rules of the Game". Ecol. Soc. 2011, 16, 16. [CrossRef]

63. Scott, J.C. Seeing Like a State: How Certain Schemes to Improve the Human Condition Have Failed; Yale Agrarian Studies; Yale University Press: New Haven, CT, USA, 1998.

64. Weinberg, M.; González, M.; Bonelli, C. Políticas de la evidencia: Entre posverdad, objetividad y etnografía. Antipoda. Rev. de Antr. y Arq. 2020, 41, 3-27. [CrossRef]

65. Chandler, J.; Davidson, A.; Harootunian, H. Questions of Evidence: Proof, Practice, and Persuasion across the Disciplines, 2nd ed.; University of Chicago Press: Chicago, IL, USA, 1994.

66. Star, S.L. Ecologies of Knowledge: Work and Politics in Science and Technology; State University of New York Press: New York, NY, USA, 1995.

67. Beck, S. The Problem of Expertise: From Experience to Skilful Practices to Expertise. Ecological and Pragmatist Perspectives. Eur. J. Pragmatism Am. Philos. 2015, 7, 8-23.

68. Boyer, D. Our Post-Post-Truth Condition. Berlin. Blatt. 2018, 80, 83-90.

69. Irwin, A.; Wynne, B. Misunderstanding Science? The Public Reconstruction of Science and Technology; Cambridge University Press: Cambridge, UK, 1996.

70. Latour, B. Why Has Critique Run Out of Steam? From Matters of Fact to Matters of Concern. Crit. Inq. 2004, 30, $225-248$.

71. Jasanoff, S. States of Knowledge: The Co-Production of Science and the Social Order; Routledge: London, UK, 2004.

72. Jasanoff, S. Humility in the Anthropocene. Globalizations 2021, 18, 839-853. [CrossRef]

73. Jackson, S.L. Abstracting Water to Extract Minerals in Mongolia's South Gobi Province. Wat. Altern. 2018, 11, 336-356.

74. Latour, B. On actor-network theory. A few clarifications plus more than a few complications. Soz. Welt 1996, 47, 369-381.

75. Tsing, A.L.; Mathews, A.S.; Bubandt, N. Patchy Anthropocene: Landscape Structure, Multispecies History, and the Retooling of Anthropology: An Introduction to Supplement 20. Curr. Anthr. 2019, 60, 186-197. [CrossRef]

76. Whitington, J. Anthropogenic Rivers: The Production of Uncertainty in Lao Hydropower; Cornell University Press: London, UK, 2018.

77. Hetherington, K. Surveying the Future Perfect: Anthropology, Development and the Promise of Infrastructure. In Infrastructures and Social Complexity: A Companion; Harvey, P., Jensen, C.B., Morita, A., Eds.; Routledge: London, UK, 2016 ; pp. 40-50.

78. Beck, M.; Krueger, T. The epistemic, ethical, and political dimensions of uncertainty in integrated assessment modeling. Wiley Interdiscip. Rev. Clim. Chang. 2016, 7, 627-645. [CrossRef]

79. Stirling, A. Keep it complex. Nature 2010, 468, 1029-1031. [CrossRef]

80. Stirling, A. Risk, precaution and science: Towards a more constructive policy debate. EMBO Rep. 2007, 8, 309-315. [CrossRef]

81. Stirling, A. "Opening Up" and "Closing Down": Power, Participation, and Pluralism in the Social Appraisal of Technology. Sci. Technol. Hum. Values 2007, 33, 262-294. [CrossRef]

82. Srinivasan, V.; Sanderson, M.; Garcia, M.; Konar, M.; Blöschl, G. Prediction in a socio-hydrological world. Hydrol. Sci. J. 2017, 62, 338-345. [CrossRef]

83. Marcus, G.E. Ethnography of the world system: The emergence of multi-Sited Ethnography. Annu. Rev. Anthropol. 1995, 24, 95-117. [CrossRef]

84. Emerson, R.; Fretz, R.; Shaw, L. Writing Ethnographic Fieldnotes; University of Chicago Press: Chicago, IL, USA, 1995.

85. DGA. Atlas del Agua. Chile 2016. 2015. Available online: https://dga.mop.gob.cl/DGADocumentos/Atlas2016parte1-17marzo2 016b.pdf (accessed on 3 May 2021).

86. MOP-DGA. Estrategia Nacional de Recursos Hídricos. 2012-2025. 2013. Available online: https://www.mop.cl/Documents/ ENRH_2013_OK.pdf (accessed on 3 May 2021).

87. Peña, H. Agua, Desarrollo y Políticas Públicas Estratégicas para la Inserción del Agua en el Desarrollo Sostenible; CEPAL: Santiago, Chile, 2004.

88. World Bank. Chile. Estudio Para el Mejoramiento del Marco Institucional Para la Gestión del Agua; World Bank: Washington, DC, USA, 2013.

89. Dirección General de Aguas (DGA). Guia para la presentación de solicitudes de derechos de aprovechamiento de aguas subterráneas. 2018. Available online: https://dga.mop.gob.cl/orientacionalpublico/guias/Guias\%20para\%20presentacion\%20 de\%20solicitudes/Guia\%20Solicitud\%20ND\%20Subterranea\%20\%20ver\%20enero\%202018.pdf (accessed on 23 September 2020).

90. Flores, T. Derechos de agua: Hasta $\$ 68$ millones puede costar el litro por segundo en Chile. Available online: https: / /www.latercera. $\mathrm{com} / \mathrm{pulso} /$ noticia/derechos-agua-68-millones-puede-costar-litro-segundo-chile/270548/ (accessed on 10 August 2021).

91. Flores, C. Servicios Sanitarios Urbanos en Chile. Revisión Crítica de Su Gestión Privatizada a Partir de la Crisis Sanitaria de Osorno; Heinrich Böll/Newenko, 2020. Available online: https://cl.boell.org/es/2020/06/16/servicios-sanitarios-urbanos-en-chile (accessed on 18 December 2020).

92. Amulén. Pobres de Agua: Radiografía del Agua Rural en Chile. Visualización de un Problema Oculto. Amulén. La Fundación del Agua. 2019. Available online: http://www.fundacionamulen.cl/wp-content/uploads/2020/07/Informe_Amulen.pdf (accessed on 5 August 2020).

93. Tapia, F. Situación del Acceso al Agua Potable en Zonas Rurales y Principales Conflictos Derivados. Actas de las Jornadas del Régimen Jurídico y Económicas en la Planificación, Gestión, Asignación y Conservación del Agua; Montenegro, S., Celume, T., Costa, E., Eds.; Facultad de Derecho, Universidad de Chile/DGA: Santiago de Chile, Chile, 2018.

94. Garreaud, R.D.; Alvarez-Garreton, C.; Barichivich, J.; Boisier, J.; Christie, D.; Galleguillos, M.; LeQuesne, C.; McPhee, J.; ZambranoBigiarini, M. The 2010-2015 Megadrought in Central Chile: Impacts on Regional Hydroclimate and Vegetation. Hydrol. Earth Syst. Sci. 2017, 21, 6307-6327. [CrossRef] 
95. Garreaud, R.D.; Boisier, J.; Rondanelli, R.; Montecinos, A.; Sepúlveda, H.; Veloso-Aguila, D. The Central Chile Mega Drought (2010-2018): A Climate Dynamics Perspective. Int. J. Clim. 2020, 40, 421-439. [CrossRef]

96. PLADECO. Plan de Desarrollo Comunal de Pica 2020-2025; Informe N.1 Diagnóstico Comunal; Ilustre Municipalidad De Pica.: Pica, Chile, 2019.

97. Larrain, S.; Poo, P. Conflictos por el Agua en Chile. Entre los Derechos Humanos y Las Reglas del Mercado; Chile Sustentable: Santiago, Chile, 2010.

98. Larraín, S. El agua en Chile: Entre los derechos humanos y las reglas del mercado. Polis Rev. Lat. 2006, 14. Available online: http://journals.openedition.org/polis/5091 (accessed on 6 December 2021).

99. OCMAL. ¿Agua o Minería? Resistencias Comunitarias en América Latina. Comunidades de Chile, Argentina y Bolivia en la Defensa de los Glaciares y el Agua Contra la Minería; Observatorio de Conflictos Mineros en América Latina: Santiago, Chile, 2020.

100. Guagama, S. Impacto de la explotación de aguas subterráneas en el oasis de Pica. In Globalización, Derechos Humanos e Indígenas; Bello, A., Aylwin, J., Eds.; Observatorio de los Derechos de Pueblos Indígenas: Temuco, Chile, 2008; pp. $387-391$.

101. Pérez, A. El oasis se muere de sed. Red Volt. 2006. Available online: http:/ / www.voltairenet.org/article141491.html (accessed on 8 July 2020).

102. Pérez, A. La sed de los Aymaras. Mineras les roban y Contaminan el agua. Available online: http://www.puntofinal.cl/611/ aymaras.htm (accessed on 5 August 2020).

103. Latour, B. From Realpolitik to Dingpolitik or how to make things public. In Making Things Public: Atmospheres of Democracy; Latour, B., Weibel, P., Eds.; MIT Press: Cambridge, MA, USA, 2005; pp. 14-43.

104. Tapia, F. Regulación de la sequía en Chile: Análisis normativo de la declaración de escasez. Revista de Derecho Administrative, 1 January 2019; No. 29.

105. Donoso, G.; Jouravlev, A.; Humberto, P.; Zegarra, E. Mercados (De Derechos) De Agua: Experiencias Y Propuestas En América Del Sur; CEPAL: Santiago, Chile, 2004.

106. Boutilier, R. A Measure of the Social License to Operate for Infrastructure and Extractive Projects. 2017. Available online: https: / / ssrn.com/abstract=3204005 (accessed on 3 September 2021).

107. Hilson, G. Corporate Social Responsibility in the Extractive Industries: Experiences from Developing Countries. Resour. Policy 2012, 37, 131-137. [CrossRef]

108. Howlett, C.; Seini, M.; McCallum, D.; Osborne, N. Neoliberalism, Mineral Development and Indigenous People: A framework for analysis. Aust. Geogr. 2011, 42, 309-323. [CrossRef]

109. Castro, L. Modernización y conflicto social. La expropiación de las aguas de regadío a los campesinos del Valle de Quisma (Oasis de Pica) y el abastecimiento fiscal a Iquique, 1880-1937; Universidad de Valparaiso: Valparaiso, Chile, 2010.

110. Swyngedouw, E. Modernity and Hybridity: Nature, Regeneracionismo, and the Production of the Spanish Waterscape, 1890-1930. Ann. Assoc. Am. Geogr. 1999, 89, 443-465. [CrossRef]

111. Babidge, S.; Bolados, P. Neoextractivism and Indigenous Water Ritual in Salar de Atacama, Chile. Lat. Am. Perspect. 2018, 45, 170-185. [CrossRef]

112. Acosta, O.; Custodio, E. Impactos ambientales de las extracciones de agua subterránea en el Salar del Huasco (Norte de Chile). Bol. Geol. Min. 2008, 119, 33-50.

113. Fuster, G.; González, L.; Morales, L.; Cerda, C.; Hernández, J.; Sotomayor, D. Estudio “Gestión Integrada de los Recursos Hídricos en Chile"; Universidad de Chile, Facultad de Ciencias Agronómicas, Departamento de Ciencia Ambientales y Recursos Naturales Renovables: Santiago de Chile, Chile, 2009.

114. Viveiros de Castro, E. Perspectival Anthropology and the Method of Controlled Equivocation. J. Soc. Anthropol. Lowl. S. Am. 2004, $2,3-22$.

115. Valverde, M. Law's Dream of a Common Knowledge; Princeton University Press: Princeton, NJ, USA, 2003.

116. Elinor, O. El Gobierno De Los Comunes. La Evolución De Las Instituciones De Acción Colectiva; UNAM-CRIM-FCE: Mexico D.F., Mexico, 2000.

117. Ballestero, A. Future History of Water; Duke University Press: London, UK, 2019.

118. Tsing, A.L. Fricctions: An Ethnography of Global Connection; Princeton University Press: Princeton, NJ, USA, 2005. 